\title{
Strategic Management: Is it an Academic Discipline?
}

Marcus Z. Cox

University of North Texas • Denton, TX

Josh Daspit

University of North Texas • Denton, TX

Erin McLaughlin

Nova Southeastern University • Fort Lauderdale-Davie, Florida

Raymond J. Jones III

University of North Texas • Denton, TX

\begin{abstract}
This paper seeks to address the question of whether strategic management is an academic discipline, as critics have argued it is not. We offer a synthesized definition of strategic management and assess whether strategic management is an academic discipline by utilizing the framework established by Biglan (1973). This framework requires disciplines to have a unifying paradigm(s) as well as practical application of its theories. After analysis, we conclude that strategic management meets Biglan's (1973) requirements and should be considered an academic discipline. In closing, we consider the future direction of strategic management research and new research methods.
\end{abstract}

\section{Introduction}

The field of strategic management is relatively young compared to other academic disciplines (e.g. economics, chemistry, law, etc.) and has been criticized by scholars who question its legitimacy and relevance. Strategic management is criticized for failing to have a concise, formal definition, lacking its own unique theories, and being a sub-field of other disciplines (Mockler, 1995; McGrath, 2007; Rumelt, Schendel, \& Teece, 1991). Additionally, the field is criticized for focusing too heavily on theory and lacking practical application for managers, for focusing too heavily on practical application and not on theory, and even for being built upon a loose set of ideas with no adequate structure (Barney, 2002; Mahoney \& McGahan, 2007; McGrath, 2007). In all, some scholars do not consider strategic management to be a viable academic discipline.

Other scholars have a different perspective. Additional assessments of strategic management indicate the existence of a demanding, complex, and refined discipline, continued growth, and a strong theoretical base with substantial empirical research (Bettis, 1991; Coyne \& Subramaniam, 1996; Hoskisson, Hitt, Wan, \& Yiu, 
1999). These contradictory statements cast an aura of uncertainty on the state of strategic management as an academic discipline.

While the aforementioned criticisms may have some level of validity, claims alone do not disqualify strategic management as a discipline. The claims merely illustrate that the field may be moving in the wrong direction or that weaknesses exist that need to be addressed. Our intention is not to negate each criticism of strategic management but instead to identify the current status of the field, utilize a framework to determine if it is a discipline, and highlight areas of concern related to its future direction.

The question of whether strategic management is an academic discipline may at first seem as though its answer is an obvious, foregone conclusion; however it is important that we answer this question using the same scientific methods we would for any research topic. Additionally, and perhaps more importantly, we should examine whether recent research in the field has taken strategic management too far away from its roots or if this diverse research stream simply represents the natural maturation of an academic field.

Furthermore, the advantages and implications of strategic management being classified as a discipline are also worthy of consideration. According to Hambrick, if strategic management is not an academic discipline, "our purpose as a field, the study of the roles of and responsibilities of general managers, will cease to have a place on the academic landscape" (2004, p. 91). If strategic management is found to not be accurately classified as an academic discipline, then our theoretical and practical contributions to management as a whole may be considered inconsequential, thus encouraging strategic management scholars to focus their efforts toward another, more stable field (Barney, 2002).

At the heart of this question is the concept of legitimacy. According to institutional theory, organizations often develop symbolic systems, artifacts, and routines not for operational efficiencies, but instead for the sake of being considered legitimate (DiMaggio \& Powell, 1983; Scott, 2001). Obtaining legitimacy is important for an academic discipline because it impacts promotion and tenure decisions, salaries, and other career opportunities. For these reasons it is important that scholars critically examine the current state of the field to determine whether we can, and should, consider strategic management a discipline.

Thus, we intend to assess the field, using procedures of scientific inquiry, to determine if strategic management should be considered an academic discipline. In addition, we address why it is important for strategic management to be classified as an academic discipline for both academicians and practitioners. While understanding 
past developments in the field are important, it is perhaps as important to understand the future direction of our field. We conclude our analysis by addressing some of the emerging research streams in strategic management and new methods of analysis. Practitioners and academicians alike should be concerned about the state of strategic management and understand the criticisms that have been leveled against it.

\section{Strategic Management Defined}

Before we address the central issue of whether strategic management is an academic discipline, we must first define strategic management. There is no consensus on a single, widely accepted definition of strategic management. The ongoing struggle with defining the field is evident in the literature as numerous definitions are used to describe strategic management. Nag, Hambrick, and Chen (2007) suggest that strategic management is difficult to define because it is a relatively new field rooted in other disciplines (e.g. economics, marketing, sociology, finance, etc.). They conclude that, "it comes as little surprise, then, that the published, espoused definitions of strategic management vary. And we can anticipate that asking strategic management scholars to define the field might elicit an array of responses" (p. 935).

Wright, Kroll, and Parnell define strategic management as "the continuous process of determining the mission and goals of an organization within the context of its external environment and its internal strengths and weaknesses, formulating appropriate strategies, implementing those strategies, and exerting strategic control to ensure the organization's strategies are successful in attaining its goals" (1996, p. 18). Additionally, Porter defines strategy as "the creation of a unique and valuable proposition, involving a different set of activities... [that differentiates the firm] from rivals" (1996, p. 67). He argues that if only one ideal position in an industry existed, then all firms would simply race to achieve the desired position. Thus, the need for strategy would not exist because success would hinge on operational effectiveness.

Next we use these descriptions, and others presented in the literature, to synthesize a definition of strategic management. The major dimensions identified in the review include: analyzing internal and external environments, formulating strategies, developing a competitive advantage, and achieving organizational goals (Bowman, Singh, \& Thomas, 2002; Bracker, 1980; Jemison, 1981; Porter, 1996; Rumelt, et al., 1994; Schendel \& Hofer, 1979; Teece, 1990; Wright, et al., 1996). In the context of this manuscript, strategic management is defined as the process by which managers of the firm analyze the internal and external environments for the 
purpose of formulating strategies and allocating resources to develop a competitive advantage in an industry that allows for the successful achievement of organizational goals. Using the given definition of strategic management, we next assess whether strategic management is an academic discipline.

\section{Assessment of Strategic Management}

A guiding framework is essential to assessing the status of an academic discipline. Biglan (1973) performed an early comparison of academic disciplines, which has been used to assess the status of several fields. Biglan (1973) postulates two primary dimensions to be used by scholars when assessing an academic discipline: the existence of a paradigm and the practical application of theory. A third dimension (related to life systems) is also proposed but is not relevant to assessments in the social sciences. The primary dimensions of Biglan's (1973) framework are in line with commonly found components in literature, which also reiterate the importance of paradigmatic developments and the practical application of knowledge in disciplines (Bird, Welsch, Astrachan, \& Pistrui, 2002; Whetten, 1989).

The primary dimensions of Biglan's (1973) model have been used either directly or indirectly to examine and define various fields of study as academic disciplines including educational technology, computer sciences, event studies and event management, pharmacy education, and journalism (Clark, 2006; Czerniewicz, 2008; de Burgh, 2003; Getz, 2002; Holmes \& Desselle, 2004). Thus, we seek to extend the application of Biglan's (1973) framework and assess the current state of strategic management. To analyze the field, primary dimensions are defined and subsequently applied to the context of strategic management for further evaluation.

\section{Paradigms}

Paradigms are important for a scientific community given that the accumulation of knowledge can only occur when members of the community adhere to an existing paradigm. Without agreement on a starting point, scientists would not be able to build on the work of others (Pfeffer, 1993). According to Kuhn (1996), a paradigm is a set of beliefs shared by a scientific community that regulates scientific research. A paradigm describes what is to be observed, what kinds of questions are to be asked, how those questions are to be structured, and how the results of the inquiry are to be interpreted (Kuhn, 1996). According to Eckberg and Hills (1979), four conditions should exist to confirm the existence of paradigms: (1) paradigms should not be discipline wide, (2) paradigms will be found within sub-disciplines 
that have considerable amounts of research, (3) paradigms must have a cohesive community of researchers that have unified bodies of belief, and (4) paradigms must be used to both generate and solve problems, thus developing a visible research tradition.

\section{Paradigms in Strategic Management}

According to Peng, Sun, Pinkham, and Chen (2009), two main paradigms exist in strategic management: the industry-based view, which came out of Industrial Organizational Economics, and the resource-based view of the firm. Industrial Organizational $(\mathrm{I} / \mathrm{O})$ theory focuses on industry structure as a key element for competition, and the notion of competitive strategy established consensus among scholars of both economics and business. Scholars of I/O theory agree that industry structure is the key determinant of profitability (Harrigan, 1980; Oster, 1982; Porter, 1981). The resource-based view of the firm is a theory of competitive advantage based not on industry structure but on unique resources of individual firms. These firm-specific resources are capable of generating rents given the existence of unique conditions (i.e., resources are valuable, rare, inimitable, and non-substitutable) that allow the firm to achieve long-term, super-normal profits (Barney, 1991; Eisenhardt \& Martin, 2000; Rumelt, 1984).

It is important to note that Kuhn believed paradigms cannot exist at a disciplinary level but rather only at the sub-disciplinary level. For example, there is no one paradigm of physics, but there are paradigms for different areas, such as the study of heat or mechanics. As for strategic management, paradigms exist in subfields such as the resource-based view and the $\mathrm{I} / \mathrm{O}$ view, yet there is no one paradigm of strategic management as a whole (Martins, 1972).

Additionally, paradigms are "unified bodies of belief shared by a cohesive community" (Eckberg \& Hills, 1979, p. 932). The existence of a paradigm assumes a community of integrated practitioners share a uniform set of beliefs such that a consensus develops around the questions asked, the methods used, interpretation of the data, and so forth (Eckberg \& Hills, 1979). Given the acceptance of the industrybased and resource-based perspectives in strategic management, we recognize that both perspectives are supported by cohesive communities of scholars.

In all, it is evident that the identified primary paradigms are not discipline wide and are found in sub-disciplines supported by a considerable amount of research. The industry and resource-based perspectives are also supported by communities of scholars who utilize the paradigms to guide problem generation and 
problem solving. Given the conditions specified, strategic management meets the criteria established for the existence of paradigms. The next criterion for assessing a discipline concerns the practical application of its theories.

\section{Practical Application}

According to the Biglan (1973) framework, the second dimension for evaluation of an academic discipline is the extent to which practical application exists within the field. Practical application is concerned with the implementation of theory to practice and is found in numerous fields. For example, in biology and energyrelated studies, new methods of producing hydrogen for use in hydrogen-based fuel cells is theorized, but the theory has not yet successfully transitioned to practice (Levin, Pitt, \& Love, 2004). Similar developments hold true in the social sciences as researchers seek to implement theory to practice. We seek to examine whether the practical application of theory exists in strategic management.

\section{Practical Application in Strategic Management}

Strategic management is considered by many to be an "applied, professional field, whose purpose is not merely to describe organizational phenomena but to predict and change them" (Gopinath \& Hoffman, 1995, p. 576). Evidence for the claim that strategic management has practical application comes from Jarzabkowski \& Giulietti (2007) whose research supports the argument that strategic management is an applied science and strategic management tools are used in business. Additionally, Benbasat and Zmud (2003) present a series of benchmarks for assessing the extent to which practical application exists in an academic discipline: (1) the institutionalization of the discipline as an integral part of today's organizational and economic contexts, (2) the acknowledgement of the importance of the field by academic accreditation bodies, (3) the presence of the academic departments and degree programs at most public and private universities, and (4) a professional society able to demonstrate influence in the organizational field.

Strategic management is institutionalized as a vital part of today's business and economic contexts. Porter's seminal work, Competitive Strategy (1980), contributed to the foundation for the growth of the strategic management field and has served as one of the most influential contributions (Barney, 2002). Porter's generic strategies "remain the most commonly supported and identified in key strategic management textbooks and in the literature" (Allen, Helms, Takeda, \& White, 2007, p. 73). Strategic management has influenced diverse fields such as global public 
health, the hospitality sector, and human resource management to name a few (Crook et al., 2006; Foster-Pedley \& Lerer, 1999; Reichel, 1983).

The AACSB (Association to Advance Collegiate Schools of Business) recognizes strategic management as viable field of study, as reflected by the number of MBA programs in strategic management which are recognized by the accrediting body. Additionally, there are numerous post-graduate programs in strategic management offered worldwide by private and public universities. Today, the presence of strategic management-oriented courses is commonplace in business programs at various levels.

Moreover, the field of strategic management contains numerous professional associations. One such professional organization is the Strategic Management Society (SMS), which consists of over 2,600 academic and business practitioners from more than sixty countries. The professional society focuses on the advancement of strategic management through the development and dissemination of knowledge pertaining to the discipline. SMS publishes three journals including the Strategic Management Journal, Strategic Entrepreneurship Journal, and the Global Strategy Journal. The Strategic Management Journal is regularly ranked as one of the top 20 business journals by Bloomberg BusinessWeek and the Financial Times. BusinessWeek also called Strategic Management Journal "one of the key indicators of business school brainpower" (Hitt, Boyd \& Li, 2004, p. 2). More than 50 percent of SMS members are from outside North America, which depicts the growth and popularity of the field globally.

Another important publication is the Journal of Business Strategies that was first published in 1984 and has consistently aimed to publish quality articles that appeal to practitioners and academicians alike (Mehta \& Bumpass, 2008). The Journal of Business Strategies was ranked by researchers in the top quartile (position 12) of 50 academic journals devoted to general management or strategy (Yuyuenyongwatana \& Carraher, 2008).

An additional example of the increasing growth trend in strategic management can be seen in the membership of the Academy of Management where there are approximately 17,800 members in Business Policy and Strategy Division with 25 percent of those members residing outside of the United States. Of the twentyfour professional divisions and interest groups within the Academy of Management, the Business Policy and Strategy Division is the second largest and growing at approximately 5 percent annually. The strong presence of professional organizations and successful journals indicates that strategic management is successfully working to apply theory to practice. 
Some researchers claim that academicians have fallen short of applying theory to practice (Baldridge, Floyd, \& Markoczy, 2004; Duncan, 1974; Gopinath \& Hoffman, 1995; Hambrick, 2007). The major criticisms being that the academic community and its theories do not keep pace with practice, the theories are not able to shape practice, and academicians are overly concerned with developing theory while losing sight of practical relevance (Jarzabkowski \& Whittington, 2008). Baldridge et al. (2004) went so far as to question whether it is possible that "academic quality and practical relevance are mutually exclusive" (2004, p. 1063).

Despite these shortcomings, researchers and practitioners have a symbiotic relationship in that one group provides for the growth and development of the other. Researchers study business practices to formulate new theory development. Once theory is abstracted from research, it is disseminated through journal articles, textbooks, MBA courses, and consultants (Jarzabkowski \& Whittington, 2008). The disseminated theory then impacts business managers who implement practices and, thus, the cycle continues. Furthermore, strategic management faculty have trained a large number of degree-seeking students and working professionals, thus having a central and substantial influence on strategic thinking and the practice of management (Mahoney \& McGahan, 2007).

Overall, strategic management has practical application in the field based on the assessment of the criteria presented by Biglan's (1973) framework for classification of an academic discipline. Although there are criticisms about academia's "theory fetish", the theories of strategic management shape business practices in a wide range of organizational areas (Hambrick, 2007). Therefore, it is determined that the field of strategic management successfully engages in practical application of theory.

\section{Assessment of Strategic Management as a Discipline Results}

We set forth to assess the current state of strategic management as an academic discipline. An assessment of the state of strategic management was performed through an analysis of the known paradigms and the level to which strategic management knowledge is practically applied. The existence of two overarching paradigms in the field provide strong support that strategic management is guided by a commonly accepted and shared network of beliefs that regulate scientific inquiry as defined by Kuhn (1996). Furthermore, additional sub-paradigms not only exist in the field but contribute to the richness of knowledge and inquiry.

An evaluation of the practical application of strategic management knowledge was also conducted. Strategic management consists of professional organiza- 
tions aimed at promoting the advancement of strategy-related literature. Moreover, Jarzabkowski and Giulietti (2007) find that the academic-practitioner gap is narrowed by the education of practitioners exposed to the tools of strategic management through training. Additionally, with the presence of strategic management degree programs and the recognition of the field by accrediting institutions, it is determined that strategic management engages in practical application.

Based on the assessment of the paradigms and practical application, it is concluded that the field of strategic management is classified as an academic discipline when evaluated using the dimensions of paradigms and practical application from Biglan's (1973) framework. The assessment of strategic management as an academic discipline is in no way intended to signal to researchers that investigations of strategic management are complete. Thus, in the next section the implications of these findings are discussed.

\section{Future Implications}

As strategic management matures as a field of academic study, it is important to address concerns about the future development of the discipline and how these concerns affect academicians and practitioners. Research indicates that the concerns regarding future developments fall into three broad categories: diversity of the research streams, adequacy of the research methods, and the extent of practical application. We review these three areas and suggest their implications for the future development of the discipline.

\section{Diversity of Research Streams}

Hambrick asserts that, "our field is rapidly being pulled apart by centrifugal forces" (2004, p. 91), and with our disparate research agendas, we run the risk of being absorbed by adjacent disciplines such as microeconomics, marketing, sociology, and psychology. Hambrick (2004) further claims that numerous strategic management scholars are in search of the next big theory, yet what is most needed is the further refinement and enhancement of existing theories. According to Kuhn (1996), after the period in revolutionary science when new paradigms are created, we enter a period of normal science where "mopping-up" activities occur (i.e., the paradigm is further clarified under more stringent conditions). Thus, Hambrick (2004) calls for members of the scientific community to "mop-up" the existing theories of strategic management instead of pursuing an endless stream of new theories. 


\section{Research Methods Development}

In light of Hambrick's (2004) recommendation, the testing of existing strategic management theory is crucial. This includes a need for more empirical articles in which predictions are grounded using existing models, diagrams, and figures to explicitly delineate the causal connections among sets of variables and indicate the critical influences that govern relationships and/or processes previously proposed by existing theory (Colquuitt \& Zapata-Phelan, 2007). The more we, as strategic management researchers, are able to underpin theories with empirical observations, the better our ability for disconfirmation (which is a primary criterion for judging theory), thus strengthening our existing theories (Van Maanen, Sorenson, \& Mitchell, 2007).

This is not to say that extension of existing theories and development of new theoretical perspectives is not important for the field. As Hoskisson, et al. (1999) noted, strategic management researchers and practitioners are constantly challenged to new, frequent, and discontinuous changes. When examining a more dynamic view of the world, whether from rapid technological changes, volatile economic conditions, or other reasons entirely, strategic problems continues to require varied theoretical perspectives and innovative empirical methodology that shape the trajectory of the field (D'Aveni, Dagnino, \& Smith, 2010). Nonetheless, Hafsi and Thomas (2005) caution that unless strategic management develops conceptual frameworks to bring research and practice together, the discipline runs the risk of being broken apart and absorbed by neighboring disciplines.

Additionally, concern about the future direction and development of the strategic management discipline is not limited to new theory development. Ketchen, Boyd, and Bergh (2008) argue that the theoretical developments in any field are only as good as the research methods used to produce them. As a field matures and advances, the research tools should also advance. In their study of strategic management journals over three time periods (1980-1982; 1990-1992; 2000-2002), Ketchen et al. (2008) discovered a dramatic increase in the volume of articles related to strategic management and the research methods employed to study the discipline. Venkatraman (2008) adds that researchers must continue to develop new methodologies while enhancing the precision of how constructs are conceptualized and relationships among them are assessed.

Strategic management theory and conceptualizations also continue to grow and spread to other respected fields and disciplines. New strategic management publications have emerged in fields such as entrepreneurship and marketing. Strategic 
Management Society (SMS) began publishing the Strategic Entrepreneurship Journal quarterly in 2007. The emphasis of the journal is to recognize the strategic nature of entrepreneurship when it adds value to society in significant, sustainable, and durable ways. Journal of Strategic Marketing has also emerged, with seven issues a year, as an outlet for publishing articles related to marketing activities that achieve organizational objectives and strategies.

Ketchen et al. (2008) also note two major weaknesses exist in strategic management's current research methods that do not properly analyze some of the key issues. First, we are limited by our use of survey instruments to "tap into executives' motives, preferences, and decisions... [and that these surveys] are quite limited in their ability to capture these nuanced phenomena" (Ketchen et al., 2008, p. 652). Next, the authors note that the issues in strategic management span multiple levels of analysis (e.g., industry, strategic group, firm, managers, etc.), and current research tools are not capable of measuring and evaluating these complex relationships.

Recent literature calls for greater use of research tools such as qualitative comparative analysis in strategic management and the application of new technologies or the use of existing methods in new ways (Greckhamer, Misangyi, Elms, \& Lacey, 2008; Venkatraman, 2008). One possible tool is DICTION, a content analysis program that may aid strategic management research by examining the impact that management narratives have on the financial and organizational performance of the firm (Short \& Palmer, 2008). Another potential resource is the greater application of critical discourse analysis in strategic management (Phillips, Sewell \& Jaynes, 2008). This methodology is useful for examining how organizations are created and maintained via discourse. Possible future areas of research using this methodology would include strategy formulation and execution of strategy.

Strategic management research would benefit from investigations using multiple levels of analysis (Hitt, Beamish, Jackson, \& Mathieu, 2007), where there is consistency between the level of theory, level of measurement (level of the entities from which data are derived), and the level of analysis (unit to which the data are assigned for hypothesis testing and statistical analysis) (Rousseau, 1985). Additional focus on causation and what it means for strategic management research is also necessary (Durand \& Vaara, 2009). Causation can be more readily addressed in strategic management through methods such as counterfactuals, which probe the direction and stability of a relationship between an event and its consequence or through the combination of laboratory and field research (Durand \& Vaara, 2009; Schwenk, 1982). In short, the lack of sufficient research tools indicates that important questions remain to be unanswered. 


\section{Practical Application Development}

Much has been written about the topic of whether strategic management literature is practical to business managers and whether research keeps pace with today's dynamic marketplace (Baldridge et al., 2004; Duncan, 1974; Gopinath \& Hoffman, 1995; Grundy, 2004; Hambrick, 2007; Jarzabkowski \& Wilson, 2006). According to our assessment, strategic management engages in practical application; yet, there are hurdles to achieving successful communication between academics and practitioners. Despite these differences, researchers and practitioners have a mutually beneficial relationship where each party assists the other in developing new theories, training management, and implementing new practices. The existence of bi-directional communication between researchers and practitioners is mutually beneficial and leads to new theory development. To further strengthen the relationship between researchers and practitioners, we recommend that researchers first engage the business community to better understand their needs while working to develop mutually beneficial research streams. The theories that we as strategic management researchers are building and advancing should be "problem-driven" to address problems and explain phenomena relevant to practice. Second, researchers are encouraged to engage in prescient scholarship to focus on future problem domains. By anticipating coming conceptual and practically relevant domains in strategic management, researchers will become less reactive. Additionally, researchers must be cognizant of communicating research-oriented lexicon in a manner appropriate for practitioners (Baldridge et al., 2004). Following this proactive approach will allow academics to communicate work that is pragmatically useful for practitioners (Corely \& Gioia, 2011).

The benefits of bridging this academic-practitioner divide are seen in what Van de Ven and Johnson (2006) label "enacted scholarship," which is a collaborative form of inquiry and bi-directional communication where academics and practitioners are able to find common ground in the questions being asked and where the design, conducting, and implementation of the research is performed in realworld settings. Leveraging perspectives and competencies from both practitioners and academics allows for a "coproduction" of knowledge about relevant problems and phenomenon. This knowledge not only becomes relevant for practitioners but academics as well. These recommendations follow Schendel, Ansoff, and Channon's recommendation - which appears in the first issue of Strategic Management Journal - that as the strategic management discipline matures, we must never lose sight of pursuing research that "both academics and practitioners would find... of interest" (1980, p. 4). 


\section{Conclusion}

Overall, this analysis intends to provide a report on the status of the field of strategic management. Specifically, the field's status as an academic discipline is determined given conflicting criticism from scholars. To evaluate the development of the field, we utilized a framework proposed by Biglan (1973) to identify two dimensions used to classify a field of study as an academic discipline. The dimensions include: having identifiable paradigms that regulate the research and having practical application to its proposed end-users. Based on our analysis of the field, we conclude that strategic management meets the criteria identified by Biglan (1973) and is an academic discipline.

The classification of strategic management as an academic discipline does not imply that the duty of strategic management scholars is any less. Moreover, it is an encouraging finding that should motivate researchers to continue refining paradigms and developing practical application to assure further enrichment. The discipline is poised to continue producing theoretical and practical advancements that will further the development of strategic management and have far-reaching implications for complementary disciplines.

\section{References}

Allen, R. S., Helms, M. M., Takeda, M. B. \& White, C. S. (2007). Porter's generic strategies: An exploratory study of their use in Japan. Journal of Business Strategies, 24(1), 69-90.

Ansoff, H. I. (1965). Corporate strategy. New York: McGraw-Hill.

Baldridge, D., Floyd, Steven W., \& Markoczy, L. (2004). Are managers from Mars and academicians from Venus: Toward an understanding of the relationship between academic quality and practical relevance. Strategic Management Journal, $25,1063-1074$.

Barney, J. B. (1991). Firm resources and sustained competitive advantage. Journal of Management, 17(1), 99-120.

Barney, J. B. (2002). Strategic management: From informed conversation to academic discipline. Academy of Management Executive, 16(2), 53-57.

Benbasat, I., \& Zmut, R. W. (2003). The identity crisis within the IS discipline: Defining and communicating the discipline's core properties. MIS Quarterly, 27(2), 183-194.

Bettis, R. (1991). Strategic management and the straightjacket: An editorial essay. Organization Science, 2(3), 315-319. 
Biglan, A. (1973). The characteristics of subject matter in different academic areas. Journal of Applied Psychology, 57(3), 195-203.

Bird, B., Welsch, H., Astrachan, J. H., \& Pistrui, D. (2002). Family business research: The evolution of an academic field. Family Business Review, 15(4), 337-350.

Bowman, E. H., Sing, H., \& Thomas, H. (2002). The domain of strategic management: Distory and evolution. In A. Pettigrew, H. Thomas, \& R. Whittington (eds.), Handbook of Strategy and Management. London: Sage.

Bracker, J. (1980). The historical development of the strategic management concept. Academy of Management Review, 5(2), 219-224.

Clark, M. (2006). A case study in the acceptance of a new discipline. Studies in Higher Education, 31(2), 133-148.

Colquitt, J. A. \& Zapata-Phelan, C. P. (2007). Trends in theory building and theory testing: A five-decade study of the Academy of Management Journal. Academy of Management Journal, 50, 1281-1303.

Corely, K. G., \& Gioia, D. A. (2011). Building theory about theory building: What constitutes a theoretical contribution? Academy of Management Review, 36(1), 12-32.

Coyne, K. P., \& Subramaniam, S. (1996). Bringing discipline to strategy. McKinsey Quarterly, 4, 14-25.

Crook, T. R., Bratton, V. K., Street, V. L., \& Ketchen, D. (2006). Has strategic management shed the normal science straightjacket?: Revisiting Bettis' (1991) critiques. Journal of Managerial Issues, 18(3), 409-423.

Czerniewicz, L. (2008). Distinguishing the field of educational technology. The Electronic Journal of e-Learning, 6(3), 171-178.

D’Aveni, R. A., Dagnino, G., Smith, K. (2010). The age of temporary advantage. Strategic Management Journal, 31, 1371-1385.

De Burgh, H. (2003). Skills are not enough: The case for journalism as an academic discipline. Journalism, 4(1), 95-112.

DiMaggio, P. J. \& Powell, W. W. (1983). The iron cage revisited: Institutional isomorphism and collective rationality in organizational field. American Sociological Review, 48, 147-160.

Duncan, W. J. (1974). Transferring management theory to practice. The Academy of Management Journal, 17(4), 724-738.

Durand, R. \& Vaara, E. (2009). Causation, counterfactuals, and competitive advantage. Strategic Management Journal, 30, 1245-1264.

Eckberg, D. L. \& Hill, L. (1979). The paradigm concept and sociology: A critical review. American Sociological Review, 44(6), 925-937. 
Eisenhardt, K. M., \& Martin, J. A. (2000). Dynamic capabilities: What are they? Strategic Management Journal, 21(10/11, Special Issue: The Evolution of Firm Capabilities, 1105-1121.

Foster-Pedley, J., \& Lerer, L. (1999). The application of strategic management theory in global public health: Towards a model of health determinants, health status and interventions. International Journal of Healthcare Technology and Management, 1(1), 148-167.

Getz, D. (2002). Event studies and event management: On becoming an academic discipline. Journal of Hospitability and Tourism Management, 9(1), 12-23.

Gopinath, C., \& Hoffman, R. C. (1995). The relevance of strategy research: Practitioner and academic viewpoints. Journal of Management Studies, 32(5), 575 594.

Greckhamer, T., Misangyi, V. F., Elms, H., \& Lacey, R. (2008). Using qualitative comparative analysis in strategic management research: An examination of combinations of industry, corporate and business-unit effects. Organizational Research Methods, 11(4), 695-726.

Grundy, T., (2004). Rejuvenating strategic management: The strategic option grid. Strategic Change, 13, 111-123.

Hafsi, T. \& Thomas, H. (2005). The field of strategy: In search of a walking stick. European Management Journal, 23(5), 507-519.

Hambrick, D. C. (2004). The disintegration of strategic management: It's time to consolidate our gains. Strategic Organization, 2(1), 91-98.

Hambrick, D. C. (2007). The field of management's devotion to theory: Too much of a good thing? Academy of Management Journal, 50(6), 1346-1352.

Harrigan, K. R. (1980). Clustering competitors by strategic groups. Proceedings of the Southwest Academy of Management Conference, San Antonio.

Hitt, M. A, Beamish, P. W., Jackson, S. E., \& Mathieu, J. E. (2007). Building theoretical and empirical bridges across levels: Multilevel research in management. Academy of Management Journal, 50, 1285-1399.

Hitt, M. A., Boyd, B. K., \& Li, D. (2004). The state of strategic management research and a vision of the future. Research Methodology in Strategy and Management, 1, 1-31.

Holmes, E., Desselle, S. (2004). Is scientific paradigm important for pharmacy education? American Journal of Pharmaceutical Education, 68(5), 1-10.

Hoskisson, R. E., Hitt, M. A., Wan, W. P., \& Yiu, D. (1999). Theory and research in strategic management: Swings of a pendulum. Journal of Management, 25(3), 417-456. 
Jarzabkowski, P., \& Giulietti, M. (2007). Strategic management as an applied science, but not as we (academics) know it. The Third Organization Studies Summer Workshop, Crete, Greece.

Jarzabkowski, P., \& Whittington, R. (2008). Directions for a troubled discipline. Journal of Management Inquiry, 17(4), 266-268.

Jarzabkowski, P., \& Wilson, D. C. (2006). Actionable strategy knowledge: A Practice Perspective. European Management Journal, 24(5), 346-367.

Jemison, D. B. (1981). The contributions of administrative behavior to strategic management. Academy of Management Review, 6(4), 633-642.

Ketchen, D., Boyd, B., \& Bergh, D., (2008). Research methodology in strategic management: Past accomplishments and future challenges. Organizational Research Methods, 11(4), 643-658.

Kuhn, T. (1996). The structure of scientific revolutions (3rd ed.). Chicago: University of Chicago Press.

Levin, D., Pitt, L., \& Love, M. (2004). Biohydrogen production: Prospects and limitations to practical application. International Journal of Hydrogen Energy, 29, 173-185.

Mahoney, J. T, \& McGahan, A. M. (2007). The field of strategic management within the evolving science of strategic organization. Strategic Organization, 5(1), 7999.

Martins, H. (1972). The Kuhnian "revolution" and its implications for sociology. In T. J. Nossiter, A. N. Hanson, \& S. Rokkan (eds.), Imagination and precision in the social sciences. London: Faber and Faber.

McGrath, R. G. (2007). No longer a stepchild: How the management field can come into its own. Academy of Management Journal, 50(6), 1365-1378.

Mehta, S. S. \& Bumpass, D. (2008). The Journal of Business Strategies: The first twenty-five years. Journal of Business Strategies, 25(2), 9-26.

Mockler, R. J. (1995). Strategic management: the beginning of a new era. International Review of Strategic Management, 6, 1-42.

Nag, R., Hambrick, D., \& Chen, M. (2007). What is strategic management, really? Inductive derivation of a consensus definition of the field, Strategic Management Journal, 28, 935-955.

Oster, S. (1982). Intra-industry structure and the ease of strategic change. Review of Economics and Statistics, 64, 376-383.

Peng, M. W., Sun, S. L., Pinkham, B., \& Chen, H. (2009). The institution-based view as a third leg for a strategy tripod. Academy of Management Perspectives, 23(3), 63-81. 
Pfeffer, J. (1993). Barriers to the advance of organizational science: Paradigm development as a dependent variable. Academy of Management Review, 18(4), 599-620.

Phillips, N., Sewell, G., \& Jaynes, S. (2008). Applying critical discourse analysis in strategic management research. Organizational Research Methods, 11(4), 770789.

Porter, M. E. (1980). Competitive strategy. New York: Free Press.

Porter, M. E. (1981) The contributions of industrial organization to strategic management. Academy of Management Review, 6, 609-620.

Porter, M. E., (1996). What is strategy?, Harvard Business Review, 61-78.

Reichel, A. (1983). Strategic management: How to apply it to firms in the hospitality industry. Service Industries Journal, 3(1), 329-343.

Rousseau, D. M. (1985). Issues of level in organizational research: Multi-level and cross-level perspectives. In L. L. Cummings \& B. M. Staw (eds.), Research in Organizational Behavior, vol. 7, 1-37.

Rumelt, R. P. (1984). Towards a strategic theory of the firm. In R. Lamb (Ed.), Competitive strategic management, 556-570. Englewood Cliffs, NJ: Prentice-Hall.

Rumelt, R. P., Schendel, D. E., \& Teece, D. J. (1991). Strategic management and economics. Strategic Management Journal, 12, 5-29.

Rumelt, R. P., Schendel, D. E., \& Teece, D. J. (1994). Fundamental issues in strategy: A research agenda. Boston: Harvard Business School Press.

Schendel, D. E., \& Hofer, C. W. (1979). Strategic management: A new view of business policy and planning. Boston: Little, Brown.

Schwenk, C. R. (1982). Why sacrifice rigour for relevance? A proposal for combining laboratory and field research in strategic management. Strategic Management Journal, 3, 213-225.

Short, J. C., \& Palmer, T. B. (2008). The application of DICTION to content analysis research in strategic management. Organizational Research Methods, 11(4), 727-752.

Scott, W. R. (2001) Institutions and organizations. Thousand Oaks, CA: Sage.

Teece, D. J. (1990). Contributions and impediments of economic analysis to the study of strategic management. In J. W. Fredrickson (ed.), Perspectives on Strategic Management, 39-80. New York: Harper Business.

Van de Ven, A., \& Johnson, P. (2006). Knowledge for theory and practice. Academy of Management Review, 31(4), 802-821.

Van Maane, J., Sorenson, J. B., \& Mitchell, T. R. (2007). The interplay between theory and method. Academy of Management Review, 32, 1145-1154. 
Venkatraman, N. V. (2008). Advancing strategic management insight: Why attention to methods and measurement matters. Organizational Research Methods, 11(4), 790-794.

Whetten, D. A. (1989). What constitutes a theoretical contribution? Academy of Management Review, 14(4), 490-495.

Wright, P., Kroll, M., \& Parnell, J. (1996). Strategic management: Concepts and cases. Englewood Cliffs, NJ: Prentice Hall.

Yuyuenyongwatana, R. P., \& Carraher, S. M. (2008). Academic journal ranking: Important to strategic management and general management researchers? Journal of Business Strategies, 25(2), 1-8.

\section{Biographical Sketch of Authors}

Marcus Z. Cox is a doctoral candidate in strategic management at the University of North Texas. He received his M.B.A. from Stephen F. Austin State University and a C.A.M. from Babson College. His current research interests are strategy, environmental sustainability, strategic innovation, and ethics.

Josh Daspit is a doctoral candidate in strategic management at the University of North Texas. He received his M.B.A. from the University of St. Thomas and his BS from Lamar University. His research interests include absorptive capacity, firm capabilities, and strategic human resource management.

Erin B. McLaughlin is an Assistant Professor in the H. Wayne Huizenga School of Business and Entrepreneurship at Nova Southeastern University. Her research interests are in the areas of strategy, small business management, entrepreneurial cognition and emotional intelligence.

Raymond Jones is currently a Ph.D. candidate in the Department of Management at the University of North Texas. He received his M.B.A. from the St. Bonaventure University and B.A. from Mercyhurst College. His current research interests focus on macro-level entrepreneurial action in the form of innovation and collaborative strategies.

\section{Acknowledgement}

The authors wish to thank Derrick D'Souza for his guidance and support and Brooklyn Cole, Victor McKee, and Ashwini Joshua for their contributions to an earlier draft. 